\title{
Environmental Chemical Contribution to the Modulation of Bile Acid Homeostasis and Farnesoid X Receptor Signaling
}

\section{Rulaiha E. Taylor ${ }^{1}$, Anisha Bhattacharya1, Grace L. Guo ${ }^{1,2,3,4}$}

1. Department of Pharmacology and Toxicology, Ernest Mario School of Pharmacy, Rutgers University, Piscataway, NJ 08854

2. Environmental and Occupational Health Sciences Institute, Rutgers, The State University of New Jersey, Piscataway, NJ 08854

3. Rutgers Center for Lipid Research, Rutgers, The State University of New Jersey, New Brunswick, NJ 08901

4. VA New Jersey Health Care System, Veterans Administration Medical Center, East Orange, NJ 07017

Corresponding Author: Grace L. Guo, MBBS, PhD, 170 Frelinghuysen Road, Piscataway, NJ, 08854 (address), (848)445-8186 (phone), (732)445-4161 (fax), guo@eohsi.rutgers.edu (e-mail)

DMD-MR-2021-000388 
Running Title: Environmental Chemicals Modulate Bile Acids and FXR Pathway

Total manuscript pages: 58

Total Figure Count: 1

Total Table Count: 2

Total word count: 11,918 


\section{Abstract}

Maintaining bile acid (BA) homeostasis is important and regulated by BA activated receptors and signaling pathways. Farnesoid $\mathrm{X}$ receptor $(\mathrm{FXR})$ and its regulated target networks in both the liver and the intestines are critical in suppressing BA synthesis and promoting BA transport and enterohepatic circulation. In addition, FXR is critical in regulating lipid metabolism and reducing inflammation, processes critical in the development of cholestasis and fatty liver diseases. BAs are modulated by but also control gut microflora. Environmental chemical exposure could affect liver disease development. However, the effects and the mechanisms by which environmental chemicals interact with FXR to affect BA homeostasis are only emerging. In this minireview, our focus is to provide evidence from reports that determine the effects of environmental or therapeutic exposure on altering homeostasis and functions of BAs and FXR. Understanding these effects will help to determine liver disease pathogenesis and provide better prevention and treatment in the future.

Significance Statement: Environmental chemical exposure significantly contributes to the development of cholestasis and non-alcoholic steatohepatitis (NASH). The impact of exposures on bile acid (BA) signaling and FXR-mediated gut-liver crosstalk is emerging. However, there is still a huge gap in understanding on how these chemicals contribute to the dysregulation of BA homeostasis and how this dysregulation may promote $\mathrm{NASH}$ development. 


\section{Abbreviations}
Abbreviation
Word
AHR
Aryl hydrocarbon receptor
AKR1B7
Aldo-keto reductase family 1 , member 7
ASBT
Apical sodium-dependent bile acid transporter
BA
Bile acid
Bacs
Bile acid-coenzyme A synthetase
Bai
Bile acid-inducible operon
BDE-47
2,29,4,49-tetrabromodiphenyl ether
BDE-99
2,29,4,49,5- pentabromodiphenyl ether
BPA
Bisphenol A
BPAF
Bisphenol AF
BPS
Bisphenol S
BSEP
Bile salt export pump
$\mathrm{BSH}$
Bile salt hydrolase
CA
Cholic acid
CAR
Constitutive androstane receptor
CDCA
Chenodeoxycholic acid
CDCA-24G
Chenodeoxycholate-24-glucoronide
CV
conventional
CYP27A1
Sterol 27-hyroxylase
CYP7A1
Cholesterol $7 \alpha$ hydroxylase
CYP7B1
25-hydroxycholesterol 7-alpha-hydroxylase 


$\begin{array}{ll}\text { CYP8B1 } & \text { Sterol 12alpha-hydroxylase } \\ \text { DCA } & \text { Deoxycholic acid } \\ \text { DDI } & \text { Drug-drug interaction } \\ \text { DDT } & \text { Dichlorodiphenyltrichloroethane } \\ \text { DLCs } & \text { Dioxins and dioxin-like compounds } \\ \text { EDC } & \text { Endocrine disrupting chemical } \\ \text { EFSA } & \text { European Food Safety Authority } \\ \text { EPA } & \text { Environmental Protection Agency } \\ \text { ERK1/2 } & \text { Extracellular signal-regulated kinase 1/2 } \\ \text { FDA } & \text { US Food and Drug Administration } \\ \text { FGF19/15 } & \text { Fibroblast growth factor 19/15 } \\ \text { FGFR4 } & \text { Fibroblast growth factor receptor 4 } \\ \text { FRET } & \text { Fluorescence resonance energy transfer } \\ \text { FXR } & \text { Farnesoid X Receptor } \\ \text { G6Pase } & \text { Glucose 6-phosphatase } \\ \text { GDCA } & \text { Glycodeoxycholic acid } \\ \text { GCDCA-S } & \text { Glycochendodeoxycholate-3-sulfate } \\ \text { GF } & \text { Germ free } \\ \text { GLCA } & \text { Gentamicin } \\ \text { GM } & \text { Hexachlorocyclohexane } \\ \text { HCH } & \text { HNF4a }\end{array}$


ICR

IFALD

I.p.

JNK1/2

LCA

MCA

MRP2

MRP3

NAFLD

$\mathrm{NASH}$

NCoR-2

NTCP

nucleoBAS

OATPs

OATP1B1

OATP1B3

OCA

OCPs

$\mathrm{OST} \alpha / \beta$

$p, p^{\prime}-D D E$

PBC

PBDE-28

PBDEs
Institute of Cancer Research

Intestinal failure-associated liver disease

Intraperitoneal

c-Jun N-terminal Kinase 1/2

Lithocholic acid

Muricholic acid

Multidrug resistance-associated protein 2

Multidrug resistance-associated protein 3

Nonalcoholic fatty liver disease

Nonalcoholic steatohepatitis

Nuclear Receptor Corepressor 2

Sodium taurocholate cotransporting polypeptide

nuclear bile acid sensor

Organic anion transporters

Solute carrier organic anion transporter family member 1B1

Solute carrier organic anion transporter family member 1B3

Obeticholic Acid

Organochlorine pesticides

Organic solute transporter alpha/beta

p,p'-dichlorodiphenyldichloroethylene

Primary biliary cholangitis/cirrhosis

2,4-Dibromo-1-(4-bromophenoxy)benzene

Polybrominated diphenyl ethers 


\begin{tabular}{|c|c|}
\hline PCBs & Polychlorinated biphenyls \\
\hline PCDDs & Polychlorinated dibenzo para dioxins \\
\hline PCDFs & Polychlorinated dibenzofurans \\
\hline PEPCK & Phosphoenolpyruvate carboxykinase \\
\hline PFAS & Per- and polyfluoroalkyl substances \\
\hline PFBS & Perfluorobutane sulfonic acid \\
\hline PFHXS & Perfluorohexane sulfonate \\
\hline PFOA & Perfluorooctanoic acid \\
\hline PFOS & Perfluorooctanesulfonic acid \\
\hline POPs & Persistent organic pollutants \\
\hline PXR & Pregnane $\mathrm{X}$ receptor \\
\hline S1PR2 & Sphingosine-1-phosphate receptor 2 \\
\hline SCD-1 & Stearoyl-CoA desaturase \\
\hline SHP & Small heterodimer partner \\
\hline SREBP-1C & Sterol regulatory element binding protein-1c \\
\hline T-aMCA & Tauro-a-muricholic acid \\
\hline T- $\beta M C A$ & Tauro- $\beta$-muricholic acid \\
\hline TCA & Taurocholic acid \\
\hline TCDCA & Taurochenodeoxycholic acid \\
\hline TCDD & 2,3,7,8- tetrachlorodibenzo para dioxin \\
\hline TCDF & 2,3,7,8-tetrachlorodibenzofuran \\
\hline TCS & Triclosan \\
\hline TDCA & Taurodeoxycholic acid \\
\hline
\end{tabular}


TGR5

TLCA

TUDCA

UDCA

VM

WT

\section{Takeda G protein-coupled receptor 5}

Taurolithocholic acid

Tauroursodeoxycholic acid

Ursodeoxycholic acid

Vancomycin

Wild-type 


\section{Introduction}

The goal of this minireview is to provide an update on the regulation of bile acid (BA) homeostasis by the nuclear receptor Farnesoid X receptor (FXR) and the effects on this regulation by exposure to environmental or therapeutic agents. BAs are critical molecules for life, and disruption of BA homeostasis has been closely linked to hepatic, intestinal and systemic diseases, including cholestasis, fatty liver diseases, and hepatic and colon tumors. Identifying the underlying molecular mechanisms by which BA regulation is disrupted by endogenous and/or xenobiotic factors will aid in not only understanding disease pathogenesis, but also providing novel strategies to prevent and/or treat diseases associated with BA dysregulation.

\section{BAs \& FXR Regulation of BA Homeostasis}

BA synthesis in the liver is the primary form of cholesterol catabolism (Fig. 1). In the liver, two major pathways carry out BA synthesis, the classical and the alternative pathway. The classical pathway is the predominant pathway, with the first and ratelimiting reaction catalyzed by a cytochrome P450 enzyme, cholesterol 7a-hydroxylase (CYP7A1). Subsequent enzymatic reactions catalyzed by sterol 12a-hydroxylase (CYP8B1) and sterol 27-hyroxylase (CYP27A1), respectively, yield the primary BAs, cholic acid (CA) and chenodeoxycholic acid (CDCA). Whereas in the alternative pathway, reactions carried out by the first enzyme, CYP27A1, followed by 25hydroxycholesterol 7a-hydroxylase (CYP7B1), produces CDCA (Russell and Setchell, 1992; Russell, 2003). Interestingly, small amounts of BAs were still detected in mice with both Cyp7a1 and Cyp27a1 gene deletion, suggesting minor BA synthetic pathways 
are present, at least in mice (Rizzolo et al., 2019a; Rizzolo et al., 2019b; Rizzolo et al., 2021). In rodents, CDCA is converted to muricholic acid (MCA), and the enzyme responsible for this conversation has been identified to be CYP2C70 (Takahashi et al., 2016; Honda et al., 2020).

Most BAs are either taurine or glycine conjugated in the liver, increasing their solubility (Fig.1) (Li and Chiang, 2014). Conjugated BAs are effluxed by bile salt export pump (BSEP) into bile canaliculi and stored in the gallbladder. During postprandial release, the gallbladder contracts releasing BAs into the duodenum. Upon reaching the small intestine, BAs function as physiological detergents that aid in the absorption of dietary triglycerides, cholesterol, and lipid-soluble vitamins (Hofmann, 1999). In the ileum, most conjugated BAs enter enterocytes via apical sodium-dependent bile acid transporter (ASBT). BAs are transported across ileocytes by the intestinal BA-binding protein (IBABP) and taken to portal circulation by the transporter heterodimer, organic solute transporters alpha and beta (OST $\alpha / \beta)$. BAs recirculate to the liver via portal circulation and are uptaken into hepatocytes by either the sodium taurocholate cotransporting polypeptide (NTCP) or organic anion transporters (OATPs) (Hagenbuch and Meier, 1994; Jacquemin et al., 1994; Wong et al., 1994; Dawson et al., 2005; Csanaky et al., 2011). Approximately $95 \%$ of BAs are recycled through enterohepatic circulation (Fig. 1). When very small amount of conjugated BAs escape the ileal reabsorption and reach to the colon, gut bacteria de-conjugate and further metabolize the primary BAs to form more hydrophobic and cytotoxic secondary BAs, including lithocholic acid (LCA) from CDCA and deoxycholic acid (DCA) from CA, through dehydrogenation, dehydroxylation 
and epimerization reactions. BAs in the large intestine are passively reabsorbed or excreted into feces.

BA synthesis is tightly regulated through a gut-liver negative feedback loop. In distal small intestine, FXR induces an endocrine fibroblast growth factor 19 (FGF19) in humans and FGF15 in mice. FGF19/15 then enters portal vein circulation to activate Fibroblast growth factor receptor 4 (FGFR4)/ßklotho complex in hepatocytes, resulting in activation of the extracellular signal-regulated kinase $1 / 2($ ERK1/2) and c-Jun Nterminal kinase 1/2 (JNK1/2) pathways to repress the expression of genes in classical pathway of BA synthesis. In the liver, activation of FXR induces small heterodimer partner (Shp) that functions to mainly suppress gene expression of CYP8B1/Cyp8b1, and to a less extent, CYP7A1/Cyp7a1 (Goodwin et al., 2000; Lu et al., 2000; Inagaki et al., 2005; Song et al., 2009; Kong et al., 2012).

BAs are endogenous signaling molecules that activate various nuclear receptors including FXR, vitamin D receptor and the pregnane $X$ receptor (PXR), as well as Gprotein coupled membrane receptors, including Takeda G-protein-coupled receptor 5 (TGR5) , muscarinic receptors 1 and 2, and the Sphingosine-1-phosphate receptor 2 (S1PR2) (Xie et al., 2001; Makishima et al., 2002; Raufman et al., 2002; Katsuma et al., 2005; Studer et al., 2012; Liu et al., 2014). Activation of FXR by BAs regulates BA homeostasis including synthesis, transport, metabolism, and detoxification (Parks et al., 1999; Li et al., 2010; Thomas et al., 2010; Kong et al., 2012; Zhan et al., 2014). FXR is crucial in the regulation and checkpoints of many genes and pathways spanning from BA enterohepatic circulation to lipid and glucose metabolism. These pathways regulate cell-signaling pathways involved in regulating lipid, glucose and energy metabolism, 
metabolic homeostasis, and inflammation. Therefore, any perturbation to BA levels and/or the composition, or regulators will have a cascade of effects on a multitude of pathways. Currently, FXR is a novel target for the therapeutic treatment of nonalcoholic steatohepatitis (NASH) (Oseini and Sanyal, 2017; Helmstädter et al., 2021; Sanyal et al., 2021; Wang et al., 2021). Nonalcoholic fatty liver disease (NAFLD) is a worldwide clinical epidemic that is most notably seen in western countries with an estimated prevalence affecting $20-30 \%$ of the population (Satapathy and Sanyal, 2015; Younossi et al., 2016). NAFLD is a spectrum of liver diseases that range from simple steatosis to inflammation. Left unattended, NASH may progress to fibrosis, cirrhosis and even hepatocellular carcinoma (Pierantonelli and Svegliati-Baroni, 2019). NASH-derived cirrhosis is currently the second leading etiology of liver disease amongst adults awaiting for liver transplantation in the United States (Satapathy and Sanyal, 2015). NASH is characterized by histopathological presence of macrovesicular steatosis, lobular inflammation, hepatic ballooning, Mallory bodies and perisinusoidal fibrosis (Brunt, 2001) NASH is a multi-factorial disease with pathogenesis not fully determined (Armstrong and Guo, 2017; Oseini and Sanyal, 2017). Confirmed diagnosis of NASH relies on an invasive and highly undesirable biopsy and there has been no US Food and Drug Administration (FDA) approved therapy for NASH currently (Sanyal et al., 2015).

FXR seems critical in NAFLD/NASH development. Activation of FXR may repress $\mathrm{NASH}$ development, which is suggested by the increase in NASH development in FXR knockout mice in a high-fat diet induced NASH model (Kong et al., 2009). During NASH development, FXR has been shown to be down-regulated (Wang et al., 2008; Zhang et al., 2009a; Zhang et al., 2009b; Bjursell et al., 2013; Porez et al., 2013; Armstrong and 
Guo, 2017). Due to the accumulated evidence that FXR plays an important role in modulating lipid homeostasis and suppressing inflammation in NASH development, FXR emerges as a major drug target to treat NASH (Sanyal et al., 2015; Chow et al., 2017; Oseini and Sanyal, 2017; Maliha and Guo, 2021).

\section{Environmental Chemicals Contribute to Modulation of BA Homeostasis}

Exposure to environmental chemicals has been demonstrated to be a significant contributor to NASH development (Cave et al., 2007). The impact of the environmental exposures on BA signaling and FXR-mediated gut-liver crosstalk has been emerging in the recent years. However, there is still a huge gap in understanding on how these chemicals impact and contribute to the regulation of BA homeostasis. The purpose of this minireview is to focus on the recent reports of the effects and mechanisms by which environmental chemicals, including pesticides, industrial plastics, per- and polyfluoroalkyl substances (PFAS), polychlorinated biphenyls (PCBs) and dioxins, alter BA homeostasis and FXR-mediated gut-liver crosstalk that may collectively contribute to NASH development in humans (Table 1).

\section{Pesticides: Herbicides, Fungicides, Insecticides}

Pesticides are a broad class of chemicals used for the prevention, destruction or control of any pests, including herbicides, fungicides and insecticides (EPA, 2021a).

\section{Organochlorine Pesticides}


Organochlorine pesticides (OCPs) are chlorinated hydrocarbons that were manufactured and used worldwide from the 1940s through the 1960s in agriculture and mosquito control. OCPs were successful in controlling malaria and typhus but are banned in most advanced countries for their adverse health effects. OCPs are resistant to environmental degradation and persistently bioaccumulate in the body, exposure to them are known to lead to reproductive disruption (Saxena et al., 1981; Beard et al., 1999), cancer (Stellman et al., 2000; Wolff et al., 2000), neurobehavioral disorders (Tilson et al., 1985; Saeedi Saravi and Dehpour, 2016), immunological toxicity (Miranda et al., 2008; Thompson et al., 2019; Shah et al., 2020) and metabolic disease (Park et al., 2010; Lee et al., 2011; Cano-Sancho et al., 2017; Han et al., 2020). The most wellknown OCPs are dichlorodiphenyltrichloroethane (DDT) and hexachlorocyclohexane $(\mathrm{HCH})$, and their major metabolites are p,p'-dichlorodiphenyldichloroethylene (p,p'-DDE) and $\beta \mathrm{HCH}$ (Salihovic et al., 2016).

Exposure to $p, p^{\prime}-\mathrm{DDE}$ and $\beta \mathrm{HCH}$ may alter BA homeostasis via both gut- and livermediated mechanisms. Chronic low dose p,p'-DDE and $\mathrm{HCH}$ exposure to adult male C57BL/6 mice for 8 weeks resulted in modulation of gut microbiota abundance and composition most notably in enhanced Lactobacillus with bile salt hydrolase (BSH) activity (Liu et al., 2017). Chronic low dose OCPs exposure significantly induced mRNA levels of BA synthesis genes Cyp7a1, Cyp8b1, and Cyp27a1 and hepatic transporters multidrug resistance-associated protein 2 (Mrp2), multidrug resistance-associated protein 3 (Mrp3), Ntcp and Bsep (Liu et al., 2017). In the ileum, OCP exposure decreased mRNA expression of genes Asbt, Osta/b and Fgf15. To test if OCP exposure 
directly affected hepatic BA synthesis, HepG2 cells treated with OCPs were found to significantly induce mRNA levels of CYP7A1, CYP8B1, CYP27A1 and BSEP (Liu et al., 2017).

Metabolomics profiling of Atlantic salmon hepatocytes exposed to $0.1,1,10$ and $100 \mu \mathrm{M}$ p,p'-DDE for 48 hours led to the upregulation of BA synthesis, decreased secretion of BAs and the reduction of glucuronidation metabolites (Olsvik and Søfteland, 2018). The proposed mechanism for increased BA synthesis is due to the very hydrophobic nature of $p, p^{\prime}-D D E, B A$ synthesis may be increased to conjugate and secrete more p,p'-DDE.

In developed countries where malaria and typhuria are well managed, the use of OCPs are banned while its derivatives continue to biomagnify; however, in developing countries, these pesticides are still widely used and therefore it is important to elucidate the potential of OCPs to cause and contribute to metabolic disease. It is known that derivatives of DDT and $\mathrm{HCH}$ alter $\mathrm{BA}$ homeostasis and more research is needed to understand the larger implications of exposure to OCPs.

\section{Endocrine Disrupting Chemicals}

\section{Bisphenols}

Bisphenol $A(B P A)$ is a known endocrine disrupting chemical (EDC) used in the production of phenol resins, polyacrylates, polyesters, epoxy resins and polycarbonate plastics. BPAs are composed of two phenol rings connected by a methyl bridge containing two methyl groups (Murata and Kang, 2018). BPA exposure leads to 
carcinogenesis, reproductive toxicity, perturbed immune response, and neurodevelopmental disorders (Murata and Kang, 2018). BPA exposure is widespread, and has been detected in water, air, and soil.

BPA may increase BA levels through altered FXR signaling, but the exact mechanism is unclear. Dietary exposure to BPA at $10 \mathrm{mg} / \mathrm{kg}$ and $10 \mathrm{mg} / \mathrm{kg}$ body weight per day during pregnancy in C57BL/6J mice induced metabolic abnormalities in F1 male offspring, and gestational glucose intolerance was also induced in pregnant mice (Susiarjo et al., 2017). At $10 \mathrm{mg} / \mathrm{kg}$ body weight per day, BPA altered lipid metabolism and increased hepatic BA levels. The altered hepatic BA levels due to BPA dietary exposure were associated with a significant decrease in Fxr and Shp mRNA expression (Susiarjo et al., 2017). Interestingly, BPA exposure did not change Cyp7a1 or Cyp8b1 gene expression, suggesting that the elevated BA levels were not due to an increase in BA synthesis, instead, it is likely that fetal transport of BAs were disrupted leading to the accumulation of BAs in the liver.

Bisphenol S (BPS) and Bisphenol AF (BPAF) are BPA analogues that are commonly used in place of BPA to comply with restrictions and regulations. In another pregnancy study, low doses of BPA, BPS and BPAF were administered at $100 \mathrm{ng} / \mathrm{g}$ body weight per day and dams were exposed until postnatal day 21. Interestingly, BPS and BPAF exposure resulted in significant increases in glucose and glycogen contents in the liver, which is associated with increased mRNA levels of Fxr and Shp, but the exact role of FXR in increased glycolysis and the inhibition of gluconeogenesis by these 
environmental chemicals is unclear (Meng et al., 2018). In an early life exposure study, CD-1 mouse dams were orally administered $0.2 \mathrm{mg} / \mathrm{kg}$ BPS daily from gestational day 8 through postnatal day 21 and this exposure to BPS in adult male pups led to an increase in fecal BAs, a decrease in beta-diversity of fecal microbiome content, specifically, there was a decreased relative abundance of a taxon in the Ruminococcaceae family and persistent increase in Lactobacillus in adult male pups, this genus is known to have bile salt hydrolase activity (Gomez et al., 2021).

Interestingly, BPS exposure in early life did not significantly alter mRNA expression of Cyp7a1 (Gomez et al., 2021). To our knowledge, this is the first study to show the effect of BPS on gut microbiome composition. These findings suggest that exposure to BPS may have a profound effect on the gut-liver axis to affect BA homeostasis (Gomez et al., 2021). Currently, there remains a large gap in understanding of how these EDCs disrupt BA homeostasis, glucose and lipid metabolism and more research is needed to further elucidate the effects and mechanisms of bisphenols on these signaling pathways.

\section{Polyflourinated Chemicals}

PFAS substances are a class of synthetic chemicals and EDCs that have been used world-wide dating back to the 1950s. PFAS include perfluorooctanoic acid PFOA), perfluorooctanesulfonic acid (PFOS), GenX chemicals or fluoropolymers and more. PFAS can be found widely in food packaging, commercial household products, production facilities or industries, drinking water and living organisms including fish, animals and humans (EPA, 2021b). Overwhelming research show that PFOS and PFOA can cause reproductive and developmental, immunological, kidney and liver toxic 
effects in vivo. PFAS structurally resemble long-chain fatty acids with fluorine in place of hydrogen. PFOS and PFOA chemicals stay persistently in the environment and human body, as they do not break down and can accumulate over time.

PFAS may alter BA homeostasis. There is strong evidence that some PFAS may undergo enterohepatic circulation. Transporter studies conducted suggest that perfluorobutane sulfonic acid (PFBS), PFHxS and PFOS are substrates of human and rat NTCP, furthermore, human ASBT can transport PFOS and human OST $\alpha / \beta$ can transport perfluorohexane sulfonate (PFHxS) and PFOS (Zhao et al., 2015). This study hypothesized that the combined BA transporter network aids in the enterohepatic recycling of PFHxS and PFOS, which may contribute to the extensive serum elimination of PFAS in humans (Zhao et al., 2015). According to the European food safety authority (EFSA) and US Environmental Protection agency (EPA), the most consistent finding of PFAS was increased cholesterol levels among exposed populations (EFSA, 2018; EPA, 2021b). PFAS have been shown to decrease fecal BA excretion (Bijland et al., 2011). This reduction of fecal BA excretion may be due to the fact that PFAS reduced the mRNA levels of Cyp7a1 and led to an increased re-uptake of BAs via enhancing the FXR-mediated negative feedback loop, which subsequently reduces de novo BA synthesis (Bijland et al., 2011; Beggs et al., 2016).

PFAS may also reduce BA synthesis through reducing hepatocyte nuclear factor 4alpha (HNF4 $\alpha$ ) levels. HNF4 $\alpha$ is a master transcriptional regulator in differentiated hepatocytes, regulating liver specific processes including BA synthesis, lipid 
metabolism, and maintenance of hepatocellular quiescence and differentiation.

Research suggest that PFOA exposure decreases HNF4a expression in hepatocytes (Watt et al., 2003). Human hepatocytes treated with occupationally relevant concentrations of PFOA and PFOS at $10 \mu \mathrm{M}$ significantly decreased HNF4a protein expression, which is associated with reduction of the expression of HNF4a target genes, including CYP7A1/Cyp7a1 (Beggs et al., 2016).

Emerging evidence suggest that PFAS may alter human BA homeostasis. In a human study, levels of PFAS and BAs were measured in 20 healthy humans (Salihović et al., 2020). In this study, the results found significant associations between plasma PFAS and BA levels. Furthermore, correlation analyses between PFAS and BA concentrations reveal a positive association with LCA, GLCA and TLCA and a negative association with GDCA. However, the majority of circulating BAs was negatively associated with PFAS, suggesting that the de novo synthesis of BAs is reduced, which is in agreement with published literature (Salihović et al., 2020). Increased levels of LCA and its conjugates could indicate a variety of scenarios including increased re-uptake of BA in the gut; decreased clearance from blood; increased production of conjugated BA in liver or decreased de-conjugation by host microbiota (Salihović et al., 2020).

\section{Polychlorinated Biphenyls}

Polychlorinated biphenyls (PCB) are a sub-group of synthetic organic chemicals that were previously manufactured and marketed around the world under the commercial name Aroclor in the early to mid-90s for their coolant and electrical insulating properties 
(Faroon and Olson, 2000; Christensen et al., 2021). Waste containing PCBs before 1977 was placed in landfills accidentally spilled and leaked in transport. As a consequence, PCBs have entered the environment and bioaccumulated (Faroon and Olson, 2000). Like PFAS, PCBs are known EDCs and do not readily break down, they can easily cycle among air, water, and soil, therefore, ongoing exposure to these chemical mixtures is extremely problematic. PCBs exist as mixtures in the environment, which makes measuring and evaluating toxicological endpoints in biological tissues of these mixtures extremely difficult (Christensen et al., 2021). The multitude of toxicities incited by PCB exposure observed in humans and animals include carcinogenicity (Dorgan et al., 1999; Stellman et al., 2000; Wolff et al., 2000), perturbations of reproductive and developmental processes (Jonsson et al., 1975; Faqi et al., 1998) and cardiovascular and metabolic functions (Choi et al., 2003; Arsenescu et al., 2008).

It is known that PCB exposure is associated with fatty liver disease; however very little is known regarding the impact that this chemical class has on the gut microbiome, and in relation to that, how BA signaling is impacted. In one recent study conducted in adult female conventional (CV) and germ-free (GF) mice, Fox River mixture, a PCB mixture, were orally administered at 6 or $30 \mathrm{mg} / \mathrm{kg}$ daily for 3 days. These treatments showed that PCBs not only alter BA gut-liver crosstalk but also bacterial involved in BA metabolism (Cheng et al., 2018).

\section{Polybrominated Diphenyl Ethers}


Polybrominated diphenyl ethers (PBDEs) are environmentally persistent organobromine compounds that may alter BA composition and levels. PBDEs were previously manufactured as flame retardants incorporated in plastics, textiles, furniture, rubber and electronic devices. Over the recent years, health concerns about exposure to PBDEs has grown as they have been found to cause developmental and reproductive toxicity, disruption in thyroid hormone homeostasis, liver toxicity and carcinogenesis in rodent models (Gascon et al., 2011; Linares et al., 2015; Pohl et al., 2017). There are 209 PBDE congeners and two of the most predominant congeners detected environmentally and in human specimens are 2,29,4,49-tetrabromodiphenyl ether (BDE-47) and 2,29,4,49,5- pentabromodiphenyl ether (BDE-99) (Erratico et al., 2011). BDE-47 and BDE-99 are known to activate Constitutive androstane receptor (CAR) and PXR in rodents and humans, two major xenobiotic sensing nuclear receptors and therefore inducing expression of cytochrome P450s, which may lead to the modulation of BA signaling (Pacyniak et al., 2007).

A well conducted study for the effects of PBDE on BA homeostasis was done in 9-week old male conventional (CV) and germ-free (GF) mice with oral administration of BDE-47 at $100 \mu \mathrm{mol} / \mathrm{kg}$ or BDE-99 at $100 \mu \mathrm{mol} / \mathrm{kg}$ once daily for 4 days, followed by extensive analysis of microbiome, transcriptome, BA profiling (Li et al., 2018). This study revealed that PBDEs altered the expression of genes involved in BA synthesis and transport at mRNA and protein levels. Specifically, the treatment of PBDEs increased Cyp7a1 mRNA levels but generally reduced the protein levels of BA synthetic enzymes and transporters. Furthermore, PBDEs changed hepatic and gut BA species, with a 
significant increase in un-conjugated BA species, likely due to alteration of gut microbiome that are involved in BA de-conjugation. This study suggests that PBDEs are not FXR modulators and presumable regulate BA homeostasis via activating CAR and/or PXR. In a study with early life PBDE exposure, BDE-47 was orally administered to CD-1 mouse dams at $0.2 \mathrm{mg} / \mathrm{kg}$ once daily from gestational day 8 through the end of lactation at postnatal day 21 . The results from study showed that exposure to BDE-47 in early life led to an increase in expression of Cyp7a1, a general trend of increase in abundance of CA, T-DCA and DCA BA metabolites and increased the abundance of the microbiome for secondary BA synthesis (Gomez et al., 2021).

PBDE exposure may lead to alternation of human microbiome. Norwegian mothers and their 1-month-old babies were analyzed for 28 environmental chemicals including 2,4Dibromo-1-(4-bromophenoxy)benzene (PBDE-28). In the breastmilk of mothers and gut bacteria in the babies, it was found that exposure to PBDE was associated with an altered infant gut microbial composition. PBDE-28 was associated with $4 \%$ less Shannon diversity and infants highly exposed to PBDE-28 had relatively less abundance of Veillonella (Iszatt et al., 2019).

These initial discoveries suggest that PBDE exposure can alter BA homeostasis, which may subsequently affect physiology and pathology associated with altered BA and lipid metabolism. 


\section{Dioxins}

Dioxins and dioxin-like compounds (DLCs) are a group of polychlorinated dibenzo para dioxins (PCDDs) and polychlorinated dibenzofurans (PCDFs) chemicals collectively called persistent organic pollutants (POPs) that are grouped together for their shared mechanism of action. Dioxins bind and activate aryl hydrocarbon receptor (AHR) and subsequently eliciting toxicity in rodents and humans (Gillner et al., 1985; Kolluri et al., 2017). Activation of AHR is widely known to mediate the expression of genes resulting in toxic responses including immune suppression, hepatotoxicity, tumor production, dermal lesions, teratogenicity and wasting dependent on sex, age and tissue (Denison et al., 2011). This is of great concern as dioxin POPS are mainly by-products of industrial processes in the production of PCBs and other chlorinated organic chemicals.

Dioxins are known to occur naturally to a lesser degree by the incomplete combustion of organic material by forest fires or volcanic activity (Pohl, 2000). Upon entering the body, dioxins are stored in adipose tissues and their estimated half-life in the body is 7 to 11 years (Pohl, 2000).

\section{TCDD}

There are 75 PCDD congeners with the most toxic one being $2,3,7,8$ tetrachlorodibenzo para dioxin (TCDD). TCDD is historically well known as a contaminant in some batches of herbicide of Agent Orange, a defoliant used during the Vietnam War, and extensively studied to date. TCDD has been well studied for its role in AHR activation and its role in eliciting hepatotoxicity. 
TCDD is known to alter expression of genes involved in cholesterol metabolism and BA biosynthesis, increase serum BA levels, decrease biliary flow, and induce bile duct epithelial cell proliferation (Pohl, 2000; Fletcher et al., 2005). In an acute study, male rats were administered a single oral dose of TCDD at 0.4 or $40 \mathrm{mg} / \mathrm{kg}$ and global analysis of gene expression was performed at 6,24 hours and 7 days following the treatment. At $40 \mathrm{mg} / \mathrm{kg}$ dosage, widespread changes in gene expression were observed in cell signaling proteins, cellular adhesion, cytoskeletal and membrane transport protein pathways (Fletcher et al., 2005). Additionally, at the high dose, there was a significantly decrease in the mRNA levels of Cyp7a1, Shp, Fxr, Ntcp and Oatp2 (Fletcher et al., 2005). The observed changes suggest TCDD exposure resulted in a major disruption of BA synthesis and transport (Fletcher et al., 2005). In a sub-acute TCDD exposure, male mice were administered TCDD by oral gavage every 4 days for 28 days at concentrations ranging between $0.01-30 \mathrm{mg} / \mathrm{kg}$, the treatments resulted in the repression of genes involved in BA synthesis and cholesterol metabolism including Cyp7a1 (Fader et al., 2017). TCDD exposure systemically altered enterohepatic circulation, despite the repression of Cyp7a1 gene expression. There was an observed increase in hepatic and serum levels of BAs, while fecal BA levels decreased, which indicates the treatment enhanced intestinal resorption as there were observed increases in ileal expression of transporters ASBT and OSTa (Fader et al., 2017).

Furthermore, TCDD increased fecal levels of $b s h$ and the bile acid-inducible (Bai) operon, suggesting there was increased gut microbiota deconjugation and 
dehydroxylation activity, which is consistent with the accumulation of TLCA and other secondary BAs (Fader et al., 2017). A similar disruption on BA homeostasis in male and female mice by TCDD was observed when it was administered to wild-type (WT) and AHR-null mice at $37 \mathrm{mg} / \mathrm{kg}$ for 5 days (Csanaky et al., 2018). In WT mice, TCDD decreased the concentration of total hepatic BAs without decreasing Cyp7a1 expression and altering the FXR-gut-liver axis (Csanaky et al., 2018). The amount of 12-OH BAs, including TCA, TDCA, CA and DCA in bile and its metabolites in the liver, T- $\alpha$ MCA, TUDCA, were decreased upon exposure to TCDD (Csanaky et al., 2018). The observed decreases in 12-OH BAs are possibly due to the decrease in Cyp8b1 mRNA expression in the liver. The observed changes were not found in AHR-null mice suggesting an AHR-dependent mechanism.

\section{TCDF}

2,3,7,8-tetrachlorodibenzofuran (TCDF), a dioxin congener with a short half-life, was found to inhibit FXR signaling via an AHR dependent manner. TCDF was administered in diet to 6-week-old male WT and AHR-null mice for 5 days at $24 \mathrm{mg} / \mathrm{kg}$ and this dietary exposure to TCDF seemed inhibit FXR signaling in WT mice resulted in a 10fold induction in Cyp7a1 mRNA levels (Zhang et al., 2015). The mRNA levels were also increased for bile acid-coenzyme A synthetase (Bacs), an important enzyme involved in conjugating BAs with taurine, which was coupled with subsequent increases in TCDCA and T-ßMCA (Zhang et al., 2015). Dietary exposure to TCDF altered gut microbiota shifting the ratio of Firmicutes to Bacteroidetes, these changes are attributed to the perturbed BA homeostasis (Zhang et al., 2015). 


\section{Bile Acids in Drug Development}

The abovementioned environmental chemicals including pesticides and industrial plastics commonly known as EDCs used in industrialization processes are known to dysregulate BA homeostasis by perturbation of BA synthesis and transport as well as by altering gut microbiome composition (Table 1). Endogenous substrates such as BAs are crucial biomarkers that are increasingly being studied to better inform drug development with respect to the prediction of drug-drug interactions. In the recent years, BAs and some of their conjugates glycochendodeoxycholate-3-sulfate (GCDCA-S) and chenodeoxycholate-24-glucoronide (CDCA-24G) have been proposed as endogenous biomarkers of hepatic transporter Solute carrier organic anion transporter family member 1B1 (OATP1B1), Solute carrier organic anion transporter family member 1B3 (OATP1B3), BSEP and NTCP in drug development (Watanabe et al., 2015; Takehara et al., 2017; Chu et al., 2018; Neuvonen et al., 2021). The use of conjugated BAs as endogenous biomarkers to inform potential drug-drug interactions (DDI) is a huge stride towards better informing risk assessment in drug development and could also potentially inform DDI management strategies. These environmental chemicals may have a potential to alter endogenous metabolism and contribute to the development of chronic liver diseases. The scientific community must develop an appreciation for BAs as more than just signaling molecules, but also explore their potential to tell us more about liver disease. More research is urgently needed to elucidate the mechanisms by which these chemicals disrupt BA homeostasis and lipid metabolism. 


\section{FXR Modulation by Environmental Contaminants}

There are few environmental chemicals known to modulate FXR signaling directly, however, several of the known chemicals to alter FXR signaling are FDA approved therapeutics that can be found in the environment in a likely unappreciable amount (Table 2). We have to point out that certain populations may be exposed to these chemicals at high amounts, e.g., occupational workers.

\section{FDA Approved Therapeutics}

FXR is an attractive therapeutic target for the treatment of several metabolic diseases including NASH (Ding et al., 2015; Chávez-Talavera et al., 2017; Oseini and Sanyal, 2017; Wang et al., 2018; Chiang and Ferrell, 2019). Currently, there are no FDAapproved therapeutics for the treatment of NASH and researchers are utilizing high throughput biochemical screening technology to identify chemicals that activate FXR to advance in the direction of finding FXR modulator(s) as potential therapy for NASH (van de Wiel et al., 2019).

In a study utilizing a nuclear BA sensor (nucleoBAS) Fluorescence Resonance Energy Transfer (FRET) technology, the FXR-activating potential of several drugs used in clinical practice was assessed utilizing WT and transfected U2-OS cells. Fifteen drugs were tested positive for FXR activation and 6 of the drugs found to activate FXR also induced FXR target gene expression (van de Wiel et al., 2019). These 6 drugs are currently widely used in clinical practice: Gliquidone for the treatment of type 2 diabetes, Nicardipine to treat hypertension, Fluticasone proprionate for anti-inflammation, 
Avermectin and Ivermectin as antiparasitics and Triclosan for its antibacterial properties (van de Wiel et al., 2019). Exposure to these therapeutics implies that there may be a greater effect on downstream FXR target proteins, and the probability of these orally administered drugs to reach the enterocytes in the intestine and activate FXR is extremely high. The exemption to this are the topical drugs such as Avermectin and Ivermectin, as their ability to penetrate the skin epithelial barrier to reach enterocytes is considerably low (van de Wiel et al., 2019).

\section{Avermectin and its derivatives}

Avermectin and its derivative Ivermectin are a series of 16-membered macrocyclic lactone derivatives generated as fermentation products by soil actinomycete for their potent insecticidal properties and widely used as an antiparasitic in animals and humans (Jin et al., 2015). Ivermectin is structurally similar to GW4064 and CDCA, and interestingly, has been found to notably induce the recruitment of nuclear receptor corepressor 2 (NCoR-2) by FXR (Jin et al., 2013). In a reporter gene assay utilizing COS-7 cells, Ivermectin was found to activate FXR in a concentration-dependent manner with an EC50 of $\sim 200 \mathrm{nM}$ (Jin et al., 2013). Ivermectin was administered by intraperitoneal injection (i.p.) for 14 days to WT and FXR KO mice fed high-fat diet to assess the effects on glucose and cholesterol metabolism in vivo. Ivermectin treatment led to a decrease in serum glucose, insulin and cholesterol levels in WT but not FXR KO mice, suggesting that Ivermectin may reduce serum glucose levels by improving insulin sensitivity in an FXR-dependent manner (Jin et al., 2013). Ivermectin treatment also induced hepatic mRNA levels of Shp while reduced those of Cyp7a1 and Cyp8b1 
in WT but not in FXR KO mice (Jin et al., 2013). Diabetic KK-Ay mice were fed a highfat diet and administered GW4064 or Ivermectin daily by i.p. injection for 14 days to further elucidate the role of Ivermectin's improvement of hyperglycemia and hyperlipidemia. Ivermectin and GW4064 significantly lowered serum cholesterol levels, and interestingly, significantly reduced Cyp7a1 and Cyp8b1 mRNA expression (Jin et al., 2013), suggesting other mechanism involved in reducing cholesterol levels. Ivermectin treatment did not elicit significant alterations in mRNA levels of genes involved in cholesterol synthesis and was found to regulate Glucose 6-phosphatase (G6Pase) and Phosphoenolpyruvate carboxykinase (Pepck) more favorably compared to GW4064 (Jin et al., 2013). These data suggest Ivermectin could potentially have an advantage over the novel GW4064 ligand with respect to regulating glucose homeostasis.

Doramectin and Abamectin are other Avermectin analogues that have shown to reduce hepatic lipid accumulation, decrease serum cholesterol and glucose levels, and improve insulin sensitivity in an FXR-dependent manner. Ten-week old KK-Ay male mice were fed a high-fat diet and administered Avermectin analogues including Doramectin, Abamectin, Ivermectin and GW4064 by i.p. injection for 14 days (Jin et al., 2015). Administration of Doramectin, Abamectin, Ivermectin to obese diabetic mice decreased liver to body weight ratios, lowered serum triglyceride and cholesterol levels, improved insulin sensitivity and significantly decreased hepatic mRNA levels of Sterol regulatory element binding protein-1c (Srebp1c) and Stearoyl-CoA desaturase (Scd1) while inducing mRNA levels of a direct FXR target gene Aldo-keto reductase family 1 , member $7(A k r 1 b 7)$, suggesting a potential mechanism in reducing de novo lipid 
synthesis in the liver (Jin et al., 2015). Avermectin and similar analogues have been used for decades for the treatment of parasitic infection in animals and humans. Perhaps this class of environmental chemicals can be repurposed as a potential therapeutic for the treatment of fatty liver diseases.

\section{Triclosan}

Triclosan (TCS) is chlorinated phenoxyphenol widely used as an antibacterial in personal care products, including toothpaste, detergents, first aid products, mouthwash, soap, and technical equipment until recently banned by the FDA in both Europe and the US. Due to the versatile nature of TCS, consumers may be exposed to this FXR activator. This is of great concern as TCS is known to be rapidly absorbed dermally and can reach systemic circulation. In the study conducted by Van de Wiel et al. (2019), TCS was found to moderately activate FXR, however, short-term treatment of TCS did not result in any changes on IBABP promoter activity nor did it induce FXR target genes (van de Wiel et al., 2019). In another experiment determining the effect on FXR activation with $50 \mu \mathrm{M}$ CDCA, TCS was found to be either a very weak agonist or a partial antagonist possibly competing with CDCA for binding of FXR (van de Wiel et al., 2019). More research is needed to fully understand the molecular mechanism by which TCS interacts with FXR and subsequent biological outcomes when interacting with gut BA pathways.

\section{Antibiotics}


The link between oral antibiotic treatment and reduced colonic microbial diversity has been well established. It is also well known that the consequence of reduced intestinal microbial diversity is associated with major shifts in the BA composition, as the gut microbiome is responsible for the generation of secondary BAs, and subsequent alterations in FXR signaling. In a single population-based cross-sectional study in pediatric patients with intestinal failure-associated liver disease (IFALD), patients were administered oral antibiotics Gentamicin (GM) or Vancomycin (VM) to prevent bacteremia and the consequences of GM and VM treatment in IFALD patients with cholestasis led to significantly lower abundance of BA-biotransforming bacteria compared to IFALD patients (Xiao et al., 2018). Specifically, the reduction in bacteria by antibiotics was associated with BA dysmetabolism and modulation of FXR signaling (Xiao et al., 2018). As a results, these patients on antibiotics presented with increased primary and decreased secondary BAs in the serum (Xiao et al., 2018). Intestinal failure patients with cholestasis exhibited disrupted FXR signaling with significant decreases in the expression of FXR target genes, Asbt and Ost $\alpha / \beta$, in ileum and a decrease in serum FGF19 (Xiao et al., 2018). FGF19 is critical to the negative-feedback regulation of BA synthesis in the liver, and in these patients with cholestasis, hepatic mRNA expression of Cyp7a1, Cyp8b1, and Cyp27a1 was significantly increased (Xiao et al., 2018). The effects of oral antibiotic were further determined in 6-week-old C57BL/6 mice administered GM $2 \mathrm{~g} / \mathrm{L}$ or VM $500 \mathrm{mg} / \mathrm{L}$ in drinking water for 2 weeks. BA metabolism in mice administered GM and VM was significantly impaired with marked alterations in intestinal microbiota composition (Xiao et al., 2018). Specifically, the antibiotic treatment increased T-BMCA in the colonic content of treated mice, a known FXR antagonist, 
which is associated with a decrease in Fgf15 and increases in Cyp7a1 gene expression (Xiao et al., 2018).

Antibiotics usage evidently plays a major role in the modulation of BA metabolism and understanding the molecular mechanisms by which antibiotics alter FXR signaling is needed as patients with NASH and other hepatic disease are likely to be administered antibiotics during their treatment regimes.

Perspective on future directions: Research from the last two decades has clearly shown the importance of maintaining BA homeostasis, regulating various biological processes by BA activated receptors and signaling pathways. However, the role of individual BAs in these processes is not entirely clear, and the effects of environmental chemicals on modulating BA homeostasis remains unclarified.

There has been an emerging appreciation for BAs as not only signaling molecules, but also potential therapeutics and biomarkers in disease initiation, progression and treatment. Furthermore, activation of FXR by synthetic ligands may not be as specific as desired. For example, a BA mimetic, obeticholic acid (OCA), is a strong synthetic FXR agonist. OCA is currently approved for the treatment of primary biliary cholangitis/cirrhosis (PBC) and may be approved for NASH therapy (NeuschwanderTetri et al., 2015). However, a very recent study showed that OCA treatment in mice led to CAR activation, which induced intestinal UGT1A1 expression and resulted in increased elimination of serum bilirubin in humanized UGT1 mice (Weber et al., 2021). Even this effect may be beneficial in treating neonates with hyperbilirubinemia, the non- 
therapeutic effects of FXR activation in other patient population may need to be evaluated. Furthermore, BAs and their conjugates have also been explored for their role as endogenous biomarkers as substrates for transporter DDI (Watanabe et al., 2015; Takehara et al., 2017; Chu et al., 2018; Neuvonen et al., 2021).

The BA-FXR axis is a critical target in NASH therapeutic development as the global epidemiological burden of $\mathrm{NASH}$ is projected to steadily increase. Understanding how exposure to environmental chemicals modulate BA signaling and homeostasis and how these exposures may contribute to liver disease pathogenesis such as NASH will greatly provide insight into NASH prevention and/or treatment.

Conclusions: In this minireview, we have focused on discussing the effects on BA homeostasis and FXR regulation with exposure to environmental chemicals or therapeutic agents. To reveal the interface between endobiotic homeostasis and xenobiotic exposure will provide mechanistic insight and preventative strategies to improve human health in the future. 


\section{Funding Footnotes:}

This work was supported by the National Institutes of Health [grant number: GM135258;

ES029258] and the Veterans Affair [grant number: BX002741].

\section{Author Contributions:}

Wrote or contributed to the writing of the manuscript: Rulaiha E. Taylor, Anisha Bhattacharya, and Grace Guo.

\section{Conflict of interest:}

No author has an actual or perceived conflict of interest with the contents of this article. 


\section{References}

Armstrong LE and Guo GL (2017) Role of FXR in Liver Inflammation during Nonalcoholic Steatohepatitis. Current pharmacology reports 3:92-100.

Arsenescu V, Arsenescu RI, King V, Swanson H, and Cassis LA (2008) Polychlorinated biphenyl-77 induces adipocyte differentiation and proinflammatory adipokines and promotes obesity and atherosclerosis. Environ Health Perspect 116:761768.

Beard AP, Bartlewski PM, and Rawlings NC (1999) Endocrine and reproductive function in ewes exposed to the organochlorine pesticides lindane or pentachlorophenol. J Toxicol Environ Health A 56:23-46.

Beggs KM, McGreal SR, McCarthy A, Gunewardena S, Lampe JN, Lau C, and Apte U (2016) The role of hepatocyte nuclear factor 4-alpha in perfluorooctanoic acidand perfluorooctanesulfonic acid-induced hepatocellular dysfunction, in: Toxicology and applied pharmacology, pp 18-29.

Bijland S, Rensen PC, Pieterman EJ, Maas AC, van der Hoorn JW, van Erk MJ, Havekes LM, Willems van Dijk K, Chang SC, Ehresman DJ, Butenhoff JL, and Princen HM (2011) Perfluoroalkyl sulfonates cause alkyl chain length-dependent hepatic steatosis and hypolipidemia mainly by impairing lipoprotein production in APOE*3-Leiden CETP mice. Toxicological sciences : an official journal of the Society of Toxicology 123:290-303.

Bjursell M, Wedin M, Admyre T, Hermansson M, Böttcher G, Göransson M, Lindén D, Bamberg K, Oscarsson J, and Bohlooly YM (2013) Ageing Fxr deficient mice 
develop increased energy expenditure, improved glucose control and liver damage resembling NASH. PLOS One 8:e64721.

Brunt EM (2001) Nonalcoholic steatohepatitis: definition and pathology. Seminars in liver disease 21:3-16.

Cano-Sancho G, Salmon AG, and La Merrill MA (2017) Association between Exposure to $p, p^{\prime}-D D T$ and Its Metabolite p,p'-DDE with Obesity: Integrated Systematic Review and Meta-Analysis. Environ Health Perspect 125:096002.

Cave M, Deaciuc I, Mendez C, Song Z, Joshi-Barve S, Barve S, and McClain C (2007) Nonalcoholic fatty liver disease: predisposing factors and the role of nutrition. $J$ Nutr Biochem 18:184-195.

Chávez-Talavera O, Tailleux A, Lefebvre P, and Staels B (2017) Bile Acid Control of Metabolism and Inflammation in Obesity, Type 2 Diabetes, Dyslipidemia, and Nonalcoholic Fatty Liver Disease. Gastroenterology 152:1679-1694.e1673.

Cheng SL, Li X, Lehmler HJ, Phillips B, Shen D, and Cui JY (2018) Gut Microbiota Modulates Interactions Between Polychlorinated Biphenyls and Bile Acid Homeostasis. Toxicological sciences : an official journal of the Society of Toxicology 166:269-287.

Chiang JYL and Ferrell JM (2019) Bile Acids as Metabolic Regulators and Nutrient Sensors. Annu Rev Nutr 39:175-200.

Choi W, Eum SY, Lee YW, Hennig B, Robertson LW, and Toborek M (2003) PCB 104induced proinflammatory reactions in human vascular endothelial cells: relationship to cancer metastasis and atherogenesis. Toxicological sciences : an official journal of the Society of Toxicology 75:47-56. 
Chow MD, Lee YH, and Guo GL (2017) The role of bile acids in nonalcoholic fatty liver disease and nonalcoholic steatohepatitis. Molecular aspects of medicine 56:3444.

Christensen K, Carlson LM, and Lehmann GM (2021) The role of epidemiology studies in human health risk assessment of polychlorinated biphenyls. Environmental Research 194:110662.

Chu X, Liao M, Shen H, Yoshida K, Zur AA, Arya V, Galetin A, Giacomini KM, Hanna I, Kusuhara H, Lai Y, Rodrigues D, Sugiyama Y, Zamek-Gliszczynski MJ, and Zhang L (2018) Clinical Probes and Endogenous Biomarkers as Substrates for Transporter Drug-Drug Interaction Evaluation: Perspectives From the International Transporter Consortium. Clin Pharmacol Ther 104:836-864.

Csanaky IL, Lickteig AJ, and Klaassen CD (2018) Aryl hydrocarbon receptor (AhR) mediated short-term effects of 2,3,7,8-tetrachlorodibenzo-p-dioxin (TCDD) on bile acid homeostasis in mice. Toxicol Appl Pharmacol 343:48-61.

Csanaky IL, Lu H, Zhang Y, Ogura K, Choudhuri S, and Klaassen CD (2011) Organic anion-transporting polypeptide $1 \mathrm{~b} 2$ (Oatp1b2) is important for the hepatic uptake of unconjugated bile acids: Studies in Oatp1b2-null mice. Hepatology (Baltimore, Md) $53: 272-281$.

Dawson PA, Hubbert M, Haywood J, Craddock AL, Zerangue N, Christian WV, and Ballatori N (2005) The heteromeric organic solute transporter alpha-beta, Ostalpha-Ostbeta, is an ileal basolateral bile acid transporter. The Journal of biological chemistry 280:6960-6968. 
Denison MS, Soshilov AA, He G, DeGroot DE, and Zhao B (2011) Exactly the same but different: promiscuity and diversity in the molecular mechanisms of action of the aryl hydrocarbon (dioxin) receptor. Toxicological sciences : an official journal of the Society of Toxicology 124:1-22.

Ding L, Yang L, Wang Z, and Huang W (2015) Bile acid nuclear receptor FXR and digestive system diseases. Acta pharmaceutica Sinica B 5:135-144.

Dorgan JF, Brock JW, Rothman N, Needham LL, Miller R, Stephenson HE, Jr., Schussler N, and Taylor PR (1999) Serum organochlorine pesticides and PCBs and breast cancer risk: results from a prospective analysis (USA). Cancer Causes Control 10:1-11.

EFSA (2018) Minutes of the expert meeting on perfluooroctane sulfonic acid and perfluorooctanoic acid in food assessment, in: Article 30 (Authority EFS ed, EFSA, UNIT on Biological Hazards and Contaminants (BIOCONTAM).

EPA (2021a) Basic Information about Pesticide Ingredients, US EPA.

EPA (2021b) Basic Information on PFAS, US EPA.

Erratico CA, Moffatt SC, and Bandiera SM (2011) Comparative oxidative metabolism of BDE-47 and BDE-99 by rat hepatic microsomes. Toxicological sciences : an official journal of the Society of Toxicology 123:37-47.

Fader KA, Nault R, Zhang C, Kumagai K, Harkema JR, and Zacharewski TR (2017) 2,3,7,8-Tetrachlorodibenzo-p-dioxin (TCDD)-elicited effects on bile acid homeostasis: Alterations in biosynthesis, enterohepatic circulation, and microbial metabolism. Sci Rep 7:5921. 
Faqi AS, Dalsenter PR, Merker HJ, and Chahoud I (1998) Effects on developmental landmarks and reproductive capability of 3,3',4,4'-tetrachlorobiphenyl and $3,3^{\prime}, 4,4^{\prime}, 5$-pentachlorobiphenyl in offspring of rats exposed during pregnancy. Hum Exp Toxicol 17:365-372.

Faroon O and Olson JN (2000) Toxicological profile for polychlorinated biphenyls (PCBs).

Fletcher N, Wahlstrom D, Lundberg R, Nilsson CB, Nilsson KC, Stockling K, Hellmold $\mathrm{H}$, and Hakansson H (2005) 2,3,7,8-Tetrachlorodibenzo-p-dioxin (TCDD) alters the mRNA expression of critical genes associated with cholesterol metabolism, bile acid biosynthesis, and bile transport in rat liver: a microarray study. Toxicol Appl Pharmacol 207:1-24.

Gascon M, Vrijheid M, Martínez D, Forns J, Grimalt JO, Torrent M, and Sunyer J (2011) Effects of pre and postnatal exposure to low levels of polybromodiphenyl ethers on neurodevelopment and thyroid hormone levels at 4 years of age. Environ Int 37:605-611.

Gillner M, Bergman J, Cambillau C, Fernström B, and Gustafsson JA (1985) Interactions of indoles with specific binding sites for 2,3,7,8-tetrachlorodibenzo-pdioxin in rat liver. Molecular pharmacology 28:357-363.

Gomez MV, Dutta M, Suvorov A, Shi X, Gu H, Mani S, and Yue Cui J (2021) Early Life Exposure to Environmental Contaminants (BDE-47, TBBPA, and BPS) Produced Persistent Alterations in Fecal Microbiome in Adult Male Mice. Toxicological sciences : an official journal of the Society of Toxicology 179:14-30. 
Goodwin B, Jones SA, Price RR, Watson MA, McKee DD, Moore LB, Galardi C, Wilson JG, Lewis MC, Roth ME, Maloney PR, Willson TM, and Kliewer SA (2000) A regulatory cascade of the nuclear receptors FXR, SHP-1, and LRH-1 represses bile acid biosynthesis. Molecular cell 6:517-526.

Hagenbuch B and Meier PJ (1994) Molecular cloning, chromosomal localization, and functional characterization of a human liver $\mathrm{Na}+/$ bile acid cotransporter. The Journal of clinical investigation 93:1326-1331.

Han X, Zhang F, Meng L, Xu Y, Li Y, Li A, Turyk ME, Yang R, Wang P, Zhang J, Zhang Q, and Jiang G (2020) Exposure to organochlorine pesticides and the risk of type 2 diabetes in the population of East China. Ecotoxicology and environmental safety 190:110125.

Helmstädter M, Kaiser A, Brunst S, Schmidt J, Ronchetti R, Weizel L, Proschak E, and Merk D (2021) Second-Generation Dual FXR/sEH Modulators with Optimized Pharmacokinetics. Journal of medicinal chemistry 64:9525-9536.

Hofmann AF (1999) The continuing importance of bile acids in liver and intestinal disease. Archives of internal medicine 159:2647-2658.

Honda A, Miyazaki T, Iwamoto J, Hirayama T, Morishita Y, Monma T, Ueda H, Mizuno S, Sugiyama F, Takahashi S, and Ikegami T (2020) Regulation of bile acid metabolism in mouse models with hydrophobic bile acid composition. Journal of lipid research 61:54-69.

Inagaki T, Choi M, Moschetta A, Peng L, Cummins CL, McDonald JG, Luo G, Jones SA, Goodwin B, Richardson JA, Gerard RD, Repa JJ, Mangelsdorf DJ, and 
Kliewer SA (2005) Fibroblast growth factor 15 functions as an enterohepatic signal to regulate bile acid homeostasis. Cell metabolism 2:217-225.

Iszatt N, Janssen S, Lenters V, Dahl C, Stigum H, Knight R, Mandal S, Peddada S, González A, Midtvedt T, and Eggesbø M (2019) Environmental toxicants in breast milk of Norwegian mothers and gut bacteria composition and metabolites in their infants at 1 month. Microbiome 7:34.

Jacquemin E, Hagenbuch B, Stieger B, Wolkoff AW, and Meier PJ (1994) Expression cloning of a rat liver $\mathrm{Na}(+)$-independent organic anion transporter. Proceedings of the National Academy of Sciences of the United States of America 91:133-137.

Jin L, Feng X, Rong H, Pan Z, Inaba Y, Qiu L, Zheng W, Lin S, Wang R, Wang Z, Wang S, Liu H, Li S, Xie W, and Li Y (2013) The antiparasitic drug ivermectin is a novel FXR ligand that regulates metabolism. Nat Commun 4:1937.

Jin L, Wang R, Zhu Y, Zheng W, Han Y, Guo F, Ye FB, and Li Y (2015) Selective targeting of nuclear receptor FXR by avermectin analogues with therapeutic effects on nonalcoholic fatty liver disease. Sci Rep 5:17288.

Jonsson HT, Jr., Keil JE, Gaddy RG, Loadholt CB, Hennigar GR, and Walker EM, Jr. (1975) Prolonged ingestion of commercial DDT and PCB; effects on progesterone levels and reproduction in the mature female rat. Arch Environ Contam Toxicol 3:479-490.

Katsuma S, Hirasawa A, and Tsujimoto G (2005) Bile acids promote glucagon-like peptide-1 secretion through TGR5 in a murine enteroendocrine cell line STC-1. Biochemical and biophysical research communications 329:386-390. 
Kolluri SK, Jin UH, and Safe S (2017) Role of the aryl hydrocarbon receptor in carcinogenesis and potential as an anti-cancer drug target. Archives of toxicology 91:2497-2513.

Kong B, Luyendyk JP, Tawfik O, and Guo GL (2009) Farnesoid X receptor deficiency induces nonalcoholic steatohepatitis in low-density lipoprotein receptor-knockout mice fed a high-fat diet. The Journal of pharmacology and experimental therapeutics 328:116-122.

Kong B, Wang L, Chiang JY, Zhang Y, Klaassen CD, and Guo GL (2012) Mechanism of tissue-specific farnesoid $\mathrm{X}$ receptor in suppressing the expression of genes in bile-acid synthesis in mice. Hepatology (Baltimore, Md) 56:1034-1043.

Lee DH, Steffes MW, Sjödin A, Jones RS, Needham LL, and Jacobs DR, Jr. (2011) Low dose organochlorine pesticides and polychlorinated biphenyls predict obesity, dyslipidemia, and insulin resistance among people free of diabetes. PLoS One 6:e15977.

Li CY, Dempsey JL, Wang D, Lee S, Weigel KM, Fei Q, Bhatt DK, Prasad B, Raftery D, Gu H, and Cui JY (2018) PBDEs Altered Gut Microbiome and Bile Acid Homeostasis in Male C57BL/6 Mice. Drug Metab Dispos 46:1226-1240.

Li G, Thomas AM, Hart SN, Zhong X, Wu D, and Guo GL (2010) Farnesoid X receptor activation mediates head-to-tail chromatin looping in the NrOb2 gene encoding small heterodimer partner. Molecular endocrinology (Baltimore, Md) 24:14041412.

Li T and Chiang JY (2014) Bile acid signaling in metabolic disease and drug therapy. Pharmacological reviews 66:948-983. 
Linares V, Bellés M, and Domingo JL (2015) Human exposure to PBDE and critical evaluation of health hazards. Archives of toxicology 89:335-356.

Liu Q, Shao W, Zhang C, Xu C, Wang Q, Liu H, Sun H, Jiang Z, and Gu A (2017) Organochloride pesticides modulated gut microbiota and influenced bile acid metabolism in mice. Environmental Pollution 226:268-276.

Liu R, Zhao R, Zhou X, Liang X, Campbell DJ, Zhang X, Zhang L, Shi R, Wang G, Pandak WM, Sirica AE, Hylemon PB, and Zhou H (2014) Conjugated bile acids promote cholangiocarcinoma cell invasive growth through activation of sphingosine 1-phosphate receptor 2. Hepatology (Baltimore, Md) 60:908-918.

Lu TT, Makishima M, Repa JJ, Schoonjans K, Kerr TA, Auwerx J, and Mangelsdorf DJ (2000) Molecular basis for feedback regulation of bile acid synthesis by nuclear receptors. Molecular cell 6:507-515.

Makishima M, Lu TT, Xie W, Whitfield GK, Domoto H, Evans RM, Haussler MR, and Mangelsdorf DJ (2002) Vitamin D receptor as an intestinal bile acid sensor. Science (New York, NY) 296:1313-1316.

Maliha S and Guo GL (2021) Farnesoid X receptor and fibroblast growth factor $15 / 19$ as pharmacological targets. Liver Research.

Meng Z, Wang D, Yan S, Li R, Yan J, Teng M, Zhou Z, and Zhu W (2018) Effects of perinatal exposure to BPA and its alternatives (BPS, BPF and BPAF) on hepatic lipid and glucose homeostasis in female mice adolescent offspring. Chemosphere 212:297-306.

Miranda AL, Roche H, Randi MA, Menezes ML, and Ribeiro CA (2008) Bioaccumulation of chlorinated pesticides and PCBs in the tropical freshwater fish Hoplias 
malabaricus: histopathological, physiological, and immunological findings. Environ Int 34:939-949.

Murata M and Kang J-H (2018) Bisphenol A (BPA) and cell signaling pathways. Biotechnology Advances 36:311-327.

Neuschwander-Tetri BA, Loomba R, Sanyal AJ, Lavine JE, Van Natta ML, Abdelmalek MF, Chalasani N, Dasarathy S, Diehl AM, Hameed B, Kowdley KV, McCullough A, Terrault N, Clark JM, Tonascia J, Brunt EM, Kleiner DE, and Doo E (2015) Farnesoid X nuclear receptor ligand obeticholic acid for non-cirrhotic, nonalcoholic steatohepatitis (FLINT): a multicentre, randomised, placebo-controlled trial. Lancet (London, England) 385:956-965.

Neuvonen M, Hirvensalo P, Tornio A, Rago B, West M, Lazzaro S, Mathialagan S, Varma M, Cerny MA, Costales C, Ramanathan R, Rodrigues AD, and Niemi M (2021) Identification of Glycochenodeoxycholate 3-O-Glucuronide and Glycodeoxycholate 3-O-Glucuronide as Highly Sensitive and Specific OATP1B1 Biomarkers. Clin Pharmacol Ther 109:646-657.

Olsvik PA and Søfteland L (2018) Metabolic effects of p,p'-DDE on Atlantic salmon hepatocytes. J Appl Toxicol 38:489-503.

Oseini AM and Sanyal AJ (2017) Therapies in non-alcoholic steatohepatitis (NASH). Liver Int 37 Suppl 1:97-103.

Pacyniak EK, Cheng X, Cunningham ML, Crofton K, Klaassen CD, and Guo GL (2007) The flame retardants, polybrominated diphenyl ethers, are pregnane $\mathrm{X}$ receptor activators. Toxicol Sci 97:94-102. 
Park SK, Son HK, Lee SK, Kang JH, Chang YS, Jacobs DR, and Lee DH (2010) Relationship between serum concentrations of organochlorine pesticides and metabolic syndrome among non-diabetic adults. J Prev Med Public Health 43:18.

Parks DJ, Blanchard SG, Bledsoe RK, Chandra G, Consler TG, Kliewer SA, Stimmel JB, Willson TM, Zavacki AM, Moore DD, and Lehmann JM (1999) Bile Acids: Natural Ligands for an Orphan Nuclear Receptor. Science (New York, NY) 284:1365.

Pierantonelli I and Svegliati-Baroni G (2019) Nonalcoholic Fatty Liver Disease: Basic Pathogenetic Mechanisms in the Progression From NAFLD to NASH. Transplantation 103:e1-e13.

Pohl H (2000) ATSDR toxicological profile for chlorinated dibenzo-p-dioxins. Toxicology and Industrial Health 16:86-201.

Pohl HR, Odin M, McClure PR, Zaccaria K, Llados F, Kawa M, and Citra M (2017) Toxicological profile for polybrominated diphenyl ethers (PBDEs).

Porez G, Gross B, Prawitt J, Gheeraert C, Berrabah W, Alexandre J, Staels B, and Lefebvre P (2013) The hepatic orosomucoid/a1-acid glycoprotein gene cluster is regulated by the nuclear bile acid receptor FXR. Endocrinology 154:3690-3701.

Raufman JP, Chen Y, Cheng K, Compadre C, Compadre L, and Zimniak P (2002) Selective interaction of bile acids with muscarinic receptors: a case of molecular mimicry. European journal of pharmacology 457:77-84.

Rizzolo D, Buckley K, Kong B, Zhan L, Shen J, Stofan M, Brinker A, Goedken M, Buckley B, and Guo GL (2019a) Bile Acid Homeostasis in a Cholesterol 7alpha- 
Hydroxylase and Sterol 27-Hydroxylase Double Knockout Mouse Model. Hepatology (Baltimore, $\mathrm{Md}$ ).

Rizzolo D, Buckley K, Kong B, Zhan L, Shen J, Stofan M, Brinker A, Goedken M, Buckley B, and Guo GL (2019b) Bile Acid Homeostasis in a Cholesterol 7aHydroxylase and Sterol 27-Hydroxylase Double Knockout Mouse Model. Hepatology (Baltimore, Md) 70:389-402.

Rizzolo D, Kong B, Taylor RE, Brinker A, Goedken M, Buckley B, and Guo GL (2021) Bile acid homeostasis in female mice deficient in Cyp7a1 and Cyp27a1. Acta Pharmaceutica Sinica B.

Russell DW (2003) The enzymes, regulation, and genetics of bile acid synthesis. Annual review of biochemistry 72:137-174.

Russell DW and Setchell KD (1992) Bile acid biosynthesis. Biochemistry 31:4737-4749. Saeedi Saravi SS and Dehpour AR (2016) Potential role of organochlorine pesticides in the pathogenesis of neurodevelopmental, neurodegenerative, and neurobehavioral disorders: A review. Life Sci 145:255-264.

Salihović S, Dickens AM, Schoultz I, Fart F, Sinisalu L, Lindeman T, Halfvarson J, Orešič M, and Hyötyläinen T (2020) Simultaneous determination of perfluoroalkyl substances and bile acids in human serum using ultra-high-performance liquid chromatography-tandem mass spectrometry. Anal Bioanal Chem 412:22512259.

Salihovic S, Ganna A, Fall T, Broeckling CD, Prenni JE, van Bavel B, Lind PM, Ingelsson $E$, and Lind L (2016) The metabolic fingerprint of p,p'-DDE and HCB exposure in humans. Environ Int 88:60-66. 
Sanyal AJ, Friedman SL, McCullough AJ, and Dimick-Santos L (2015) Challenges and opportunities in drug and biomarker development for nonalcoholic steatohepatitis: findings and recommendations from an American Association for the Study of Liver Diseases-U.S. Food and Drug Administration Joint Workshop. Hepatology (Baltimore, Md) 61:1392-1405.

Sanyal AJ, Ling L, Beuers U, DePaoli AM, Lieu HD, Harrison SA, and Hirschfield GM (2021) Potent suppression of hydrophobic bile acids by aldafermin, an FGF19 analogue, across metabolic and cholestatic liver diseases. JHEP Rep 3:100255.

Satapathy SK and Sanyal AJ (2015) Epidemiology and Natural History of Nonalcoholic Fatty Liver Disease. Seminars in liver disease 35:221-235.

Saxena MC, Siddiqui MK, Bhargava AK, Murti CR, and Kutty D (1981) Placental transfer of pesticides in humans. Archives of toxicology 48:127-134.

Shah HK, Sharma T, and Banerjee BD (2020) Organochlorine pesticides induce inflammation, ROS production, and DNA damage in human epithelial ovary cells: An in vitro study. Chemosphere 246:125691.

Song KH, Li T, Owsley E, Strom S, and Chiang JY (2009) Bile acids activate fibroblast growth factor 19 signaling in human hepatocytes to inhibit cholesterol 7alphahydroxylase gene expression. Hepatology (Baltimore, Md) 49:297-305.

Stellman SD, Djordjevic MV, Britton JA, Muscat JE, Citron ML, Kemeny M, Busch E, and Gong $L$ (2000) Breast cancer risk in relation to adipose concentrations of organochlorine pesticides and polychlorinated biphenyls in Long Island, New York. Cancer Epidemiol Biomarkers Prev 9:1241-1249. 
Studer E, Zhou X, Zhao R, Wang Y, Takabe K, Nagahashi M, Pandak WM, Dent P, Spiegel S, Shi R, Xu W, Liu X, Bohdan P, Zhang L, Zhou H, and Hylemon PB (2012) Conjugated bile acids activate the sphingosine-1-phosphate receptor 2 in primary rodent hepatocytes. Hepatology (Baltimore, Md) 55:267-276.

Susiarjo M, Xin F, Stefaniak M, Mesaros C, Simmons RA, and Bartolomei MS (2017) Bile Acids and Tryptophan Metabolism Are Novel Pathways Involved in Metabolic Abnormalities in BPA-Exposed Pregnant Mice and Male Offspring. Endocrinology 158:2533-2542.

Takahashi S, Fukami T, Masuo Y, Brocker CN, Xie C, Krausz KW, Wolf CR, Henderson CJ, and Gonzalez FJ (2016) Cyp2c70 is responsible for the species difference in bile acid metabolism between mice and humans. Journal of lipid research $57: 2130-2137$.

Takehara I, Terashima H, Nakayama T, Yoshikado T, Yoshida M, Furihata K, Watanabe N, Maeda K, Ando O, Sugiyama Y, and Kusuhara H (2017) Investigation of Glycochenodeoxycholate Sulfate and Chenodeoxycholate Glucuronide as Surrogate Endogenous Probes for Drug Interaction Studies of OATP1B1 and OATP1B3 in Healthy Japanese Volunteers. Pharm Res 34:1601-1614.

Thomas AM, Hart SN, Kong B, Fang J, Zhong XB, and Guo GL (2010) Genome-wide tissue-specific farnesoid $\mathrm{X}$ receptor binding in mouse liver and intestine. Hepatology (Baltimore, Md) 51:1410-1419.

Thompson LA, Ikenaka Y, Sobhy Darwish W, Nakayama SMM, Mizukawa H, and Ishizuka M (2019) Effects of the organochlorine p,p'-DDT on MCF-7 cells: 
Investigating metabolic and immune modulatory transcriptomic changes. Environ Toxicol Pharmacol 72:103249.

Tilson HA, Hong JS, and Mactutus CF (1985) Effects of 5,5-diphenylhydantoin (phenytoin) on neurobehavioral toxicity of organochlorine insecticides and permethrin. The Journal of pharmacology and experimental therapeutics 233:285-289.

van de Wiel SMW, Bijsmans ITGW, van Mil SWC, and van de Graaf SFJ (2019) Identification of FDA-approved drugs targeting the Farnesoid X Receptor. Scientific Reports 9:2193.

Wang H, He Q, Wang G, Xu X, and Hao H (2018) FXR modulators for enterohepatic and metabolic diseases. Expert Opin Ther Pat 28:765-782.

Wang Y, Crittenden DB, Eng C, Zhang Q, Guo P, Chung D, Fenaux M, Klucher K, Jones C, Jin F, Quirk E, and Charlton MR (2021) Safety, Pharmacokinetics, Pharmacodynamics, and Formulation of Liver-Distributed Farnesoid X-Receptor Agonist TERN-101 in Healthy Volunteers. Clin Pharmacol Drug Dev 10:11981208.

Wang YD, Chen WD, Wang M, Yu D, Forman BM, and Huang W (2008) Farnesoid X receptor antagonizes nuclear factor kappaB in hepatic inflammatory response. Hepatology (Baltimore, Md) 48:1632-1643.

Watanabe T, Miyake M, Shimizu T, Kamezawa M, Masutomi N, Shimura T, and Ohashi R (2015) Utility of bilirubins and bile acids as endogenous biomarkers for the inhibition of hepatic transporters. Drug Metab Dispos 43:459-466. 
Watt AJ, Garrison WD, and Duncan SA (2003) HNF4: A central regulator of hepatocyte differentiation and function. Hepatology (Baltimore, Md) 37:1249-1253.

Weber AA, Mennillo E, Yang X, van der Schoor LWE, Jonker JW, Chen S, and Tukey $\mathrm{RH}$ (2021) Regulation of Intestinal UDP-Glucuronosyltransferase 1A1 by the Farnesoid X Receptor Agonist Obeticholic Acid Is Controlled by Constitutive Androstane Receptor through Intestinal Maturation. Drug Metab Dispos 49:1219.

Wolff MS, Zeleniuch-Jacquotte A, Dubin N, and Toniolo P (2000) Risk of breast cancer and organochlorine exposure. Cancer Epidemiol Biomarkers Prev 9:271-277.

Wong MH, Oelkers P, Craddock AL, and Dawson PA (1994) Expression cloning and characterization of the hamster ileal sodium-dependent bile acid transporter. The Journal of biological chemistry 269:1340-1347.

Xiao Y, Zhou K, Lu Y, Yan W, Cai W, and Wang Y (2018) Administration of antibiotics contributes to cholestasis in pediatric patients with intestinal failure via the alteration of FXR signaling. Exp Mol Med 50:1-14.

Xie W, Radominska-Pandya A, Shi Y, Simon CM, Nelson MC, Ong ES, Waxman DJ, and Evans RM (2001) An essential role for nuclear receptors SXR/PXR in detoxification of cholestatic bile acids. Proceedings of the National Academy of Sciences of the United States of America 98:3375-3380.

Younossi ZM, Koenig AB, Abdelatif D, Fazel Y, Henry L, and Wymer M (2016) Global epidemiology of nonalcoholic fatty liver disease-Meta-analytic assessment of prevalence, incidence, and outcomes. Hepatology (Baltimore, Md) 64:73-84. 
Zhan L, Liu HX, Fang Y, Kong B, He Y, Zhong XB, Fang J, Wan YJ, and Guo GL (2014) Genome-wide binding and transcriptome analysis of human farnesoid $\mathrm{X}$ receptor in primary human hepatocytes. PLoS One 9:e105930.

Zhang L, Nichols RG, Correll J, Murray IA, Tanaka N, Smith PB, Hubbard TD, Sebastian A, Albert I, Hatzakis E, Gonzalez FJ, Perdew GH, and Patterson AD (2015) Persistent Organic Pollutants Modify Gut Microbiota-Host Metabolic Homeostasis in Mice Through Aryl Hydrocarbon Receptor Activation. Environ Health Perspect 123:679-688.

Zhang S, Liu Q, Wang J, and Harnish DC (2009a) Suppression of interleukin-6-induced C-reactive protein expression by FXR agonists. Biochemical and biophysical research communications 379:476-479.

Zhang S, Wang J, Liu Q, and Harnish DC (2009b) Farnesoid X receptor agonist WAY362450 attenuates liver inflammation and fibrosis in murine model of nonalcoholic steatohepatitis. Journal of hepatology 51:380-388.

Zhao W, Zitzow JD, Ehresman DJ, Chang SC, Butenhoff JL, Forster J, and Hagenbuch B (2015) Na+/Taurocholate Cotransporting Polypeptide and Apical SodiumDependent Bile Acid Transporter Are Involved in the Disposition of Perfluoroalkyl Sulfonates in Humans and Rats. Toxicological sciences : an official journal of the Society of Toxicology 146:363-373. 


\section{Figure Captions}

\section{Fig. 1. Suppression of BA Synthesis Mediated by FXR Signaling}

Primary bile acids (BAs) are synthesized in hepatocytes by two pathways: the classical pathway initiated by CYP7A1 and the alternative pathway initiated by CYP27A1. Cholic acid (CA) and Chenodeoxycholic acid (CDCA) are the most prevalent primary BAs in humans. In mice, primary BAs are $C A$ and alpha/beta muricholic acids $(\alpha / \beta-M C A)$. CDCA is the precursor for $\alpha-M C A$ as well as the precursor for the ursodeoxycholic acid (UDCA) which is then synthesized to $\beta-M C A$ via CYP2C70. Primary BAs are conjugated and in humans, BAs undergo both glycine and taurine conjugation, with a preference for glycine conjugation. In mice, almost all BAs are taurine conjugated. Following conjugation, BAs are transported out of the liver via bile salt export pumps (BSEPs) to the gallbladder and then to the small intestine. BAs are taken up in the small intestine by way of the transporter Apical sodium dependent bile acid transporter (ASBT). Once in the small intestine, BAs are deconjugated and undergo additional modifications facilitated by bacterial microbiomes in the gut. The resulting BAs are secondary BAs, deoxycholic acid (DCA) and Lithocholic acid (LCA) in humans and murideoxycholic acid (MDCA) in mice. BAs are also integral signaling molecules. BAs are endogenous ligands for many receptors, the best known receptor being farnesoid $X$ receptor (FXR). In the liver, FXR induces its target gene small heterodimer partner (SHP) to inhibit gene expression of CYP7A1/Cyp7a1 and CYP8B1/Cyp8b1, acting as negative feedback regulation for BA synthesis. In the small intestine, FXR induces FGF19 in humans and FGF15 in mice. FGF19/15 then enters portal vein circulation to activate FGFR4/ßKlotho complex in hepatocytes, which activates the ERK1/2 and JNK1/2 pathways to inhibit gene expression in classical pathway of BA synthesis. BAs also enter portal vein 
circulation, leaving the intestine via the transporter dimer organic solute transporter alpha/beta (OST $\alpha / \beta)$. Sodium/taurocholate cotransporting polypeptide (NTCP) transports conjugated BAs back to the liver whereas organic anion transporting polypeptides (OATPs) transport unconjugated BAs back to the liver. Figure was made with biorender.com. 
Table 1. Environmental Chemicals Known to Modulate Bile Acid Signaling

\begin{tabular}{|c|c|c|c|c|}
\hline Chemical & Model & Exposure & $\begin{array}{c}\text { Physiological and Molecular } \\
\text { Endpoint }\end{array}$ & Citation \\
\hline \multirow[t]{2}{*}{$\begin{array}{c}p, p^{\prime}-D D E \\
\beta-H C H\end{array}$} & $\begin{array}{l}\mathrm{C} 57 \mathrm{BL} / 6 \\
\text { mice }\end{array}$ & $\begin{array}{l}\mathrm{p}, \mathrm{p} '-\mathrm{DDE} 1 \\
\mathrm{mg} / \mathrm{kg} \text { bw/day } \\
\beta-\mathrm{HCH} 10 \\
\mathrm{mg} / \mathrm{kg} \text { bw/day; } \\
8 \text { weeks }\end{array}$ & $\begin{array}{l}\uparrow \text { Cyp7a1, Cyp8b1, Cyp27a1 } \\
\text { mRNA } \\
\text { \ileal BA reabsorption } \\
\uparrow \text { hepatic BA synthesis modulation } \\
\text { of gut microbiota abundance and } \\
\text { composition }\end{array}$ & \multirow[t]{2}{*}{$\begin{array}{l}\text { Liu et al., } \\
2017\end{array}$} \\
\hline & HepG2 cells & $\begin{array}{l}\mathrm{p}, \mathrm{p}^{\prime}-\mathrm{DDE} 10 \\
\mathrm{ng} / \mathrm{mL} \\
\beta-\mathrm{HCH} 100 \\
\text { ng/mL; } \\
\text { duration } \\
\text { unknown }\end{array}$ & $\begin{array}{l}\uparrow \text { CYP7A1, CYP8B1, CYP27A1, } \\
\text { BSEP mRNA }\end{array}$ & \\
\hline$p, p^{\prime}-D D E$ & $\begin{array}{c}\text { Atlantic } \\
\text { salmon } \\
\text { hepatocytes }\end{array}$ & $\begin{array}{c}0.1,1,10,100 \\
\mu \mathrm{M} ; 48 \mathrm{hrs}\end{array}$ & $\begin{array}{l}\uparrow \text { BA synthesis, albumin synthesis } \\
\downarrow \text { secretion of BAs, glucoronidation } \\
\text { metabolites }\end{array}$ & $\begin{array}{l}\text { Olsvik \& } \\
\text { Søfteland, } \\
2018\end{array}$ \\
\hline BPA & $\begin{array}{l}\mathrm{C} 57 \mathrm{BL} / 6 \\
\text { mice }\end{array}$ & $\begin{array}{l}10 \mu \mathrm{g} / \mathrm{kw} \text { bw, } \\
10 \mathrm{mg} / \mathrm{kg} \mathrm{bw} \text {; } \\
\text { during } \\
\text { pregnancy }\end{array}$ & $\begin{array}{l}\text { gestational glucose intolerance in } \\
\text { F0 pregnant mice } \\
\text { metabolic abnormalities in F1 male } \\
\text { offspring } \\
\leftrightarrow \text { Cyp7a1, Cyp8b1 mRNA } \\
10 \text { mg/kg bw: altered lipid } \\
\text { metabolism, } \uparrow \text { hepatic BA levels, } \\
\downarrow F x r, \text { Shp mRNA }\end{array}$ & $\begin{array}{l}\text { Susiarjo et } \\
\text { al., } 2017\end{array}$ \\
\hline $\begin{array}{l}\text { BPA } \\
\text { BPS } \\
\text { BPAF }\end{array}$ & $\begin{array}{l}\text { Primigravida } \\
\text { pregnant } \\
\text { Institute of } \\
\text { Cancer } \\
\text { Research } \\
\text { (ICR) mice }\end{array}$ & $\begin{array}{l}100 \mathrm{ng} / \mathrm{g} \\
\text { bw/day; } \\
\text { duration of } \\
\text { pregnancy } \\
\text { until postnatal } \\
\text { day } 21\end{array}$ & $\begin{array}{l}\text { BPS and BPAF: } \\
\uparrow \text { glucose, glycogen in liver } \\
\uparrow \text { mRNA of Fxr, Shp, and genes } \\
\text { related to glucose and lipid } \\
\text { metabolism }\end{array}$ & $\begin{array}{l}\text { Meng et } \\
\text { al., } 2018\end{array}$ \\
\hline BPS & CD-1 mice & $\begin{array}{l}0.2 \mathrm{mg} / \mathrm{kg} / \mathrm{day} ; \\
\text { gestational } \\
\text { day } 8 \text { through } \\
\text { postnatal day } \\
21\end{array}$ & $\begin{array}{l}\text { Adult male pups: } \\
\uparrow \text { fecal BAs } \\
\downarrow \beta \text {-diversity of Ruminococcaceae } \\
\text { family } \\
\uparrow \text { Lactobacillus } \\
\leftrightarrow \text { Cyp7a1 mRNA } \\
\downarrow \text { IL-2, IL-12p35, IL-12p40, Nqo1 } \\
\text { mRNA }\end{array}$ & $\begin{array}{l}\text { Gomez et } \\
\text { al., } 2021\end{array}$ \\
\hline PFAS & Human & - & $\begin{array}{l}\text { positive association between } \\
\text { PFAS and BAs for LCA, GLCA, } \\
\text { TLCA }\end{array}$ & $\begin{array}{l}\text { Salihović } \\
\text { et al., } 2020\end{array}$ \\
\hline
\end{tabular}




\begin{tabular}{|c|c|c|c|c|}
\hline & & & $\begin{array}{l}\text { negative association between } \\
\text { PFAS and BAs for GDCA }\end{array}$ & \\
\hline PCB & $\begin{array}{l}\text { C57BL/6 } \\
\text { mice } \\
\text { Conventional } \\
\text { Germ free }\end{array}$ & $\begin{array}{c}6 \mathrm{mg} / \mathrm{kg} \text { daily, } \\
30 \mathrm{mg} / \mathrm{kg} \\
\text { daily; } 3 \text { days }\end{array}$ & $\begin{array}{l}\text { altered gut microbiome } \\
\text { composition, modulated BA } \\
\text { homeostasis } \\
\text { at } 30 \mathrm{mg} / \mathrm{kg} \text { increased hepatic } \\
\text { efflux transporter expression, ileal } \\
\text { Fgf15 }\end{array}$ & $\begin{array}{l}\text { Cheng et } \\
\text { al., } 2018\end{array}$ \\
\hline $\begin{array}{l}\text { PBDE-47 } \\
\text { PBDE-99 }\end{array}$ & $\begin{array}{l}\text { C57BL/6 } \\
\text { mice }\end{array}$ & $\begin{array}{l}\text { BDE-47 } 100 \\
\mu \mathrm{mol} / \mathrm{kg} / \text { daily } \\
\text { BDE-99 } \\
\mu \mathrm{mol} / \mathrm{kg} / \text { daily; } \\
4 \text { days }\end{array}$ & $\begin{array}{l}\uparrow \text { Akkermansia muciniphila and } \\
\text { Erysipelotri- chaceae Allobaculum } \\
\text { spp., } \\
\downarrow \text { BA-synthesizing enzymes BSEP, } \\
\text { NTCP, OATP1B2 Protein levels } \\
\uparrow \text { Cyp7a1 mRNA }\end{array}$ & $\begin{array}{c}\text { Li et al., } \\
2018\end{array}$ \\
\hline PBDE-47 & CD-1 mice & $\begin{array}{l}0.2 \mathrm{mg} / \mathrm{kg} / \mathrm{day} ; \\
\text { gestational } \\
\text { day } 8 \text { through } \\
\text { postnatal day } \\
21\end{array}$ & $\begin{array}{l}\uparrow \text { Cyp7a1 mRNA } \\
\uparrow \text { abundance of CA, T-DCA and } \\
\text { DCA BA metabolites } \\
\uparrow \text { abundance of the genus Blautia, } \\
\text { Ruminococcus genus, and } \\
\text { Lachnospiraceae }\end{array}$ & $\begin{array}{l}\text { Gomez et } \\
\text { al., } 2021\end{array}$ \\
\hline PBDE-28 & Human & - & $\begin{array}{l}\text { altered infant gut microbial } \\
\text { composition } \\
\downarrow \text { abundance of Veillonella }\end{array}$ & $\begin{array}{l}\text { Iszatt et } \\
\text { al., } 2019\end{array}$ \\
\hline \multirow[t]{3}{*}{ TCDD } & $\begin{array}{c}\text { Sprague- } \\
\text { Dawley rats }\end{array}$ & $\begin{array}{l}\text { TCDD } 0.1 \\
\mu g / k w \text { bw, } 40 \\
\mu g / k g \text { bw; } 6 \\
\text { hrs, } 24 \mathrm{hrs}, 7 \\
\text { days }\end{array}$ & $\begin{array}{l}\text { at } 40 \mu \mathrm{g} / \mathrm{kg} \text { : } \\
\downarrow \text { Cyp7a1, Shp, Fxr, Ntcp, Oatp2 } \\
\text { mRNA } \\
\text { widespread changes in cell } \\
\text { signaling, cellular adhesion, } \\
\text { cytoskeletal and membrane } \\
\text { transport protein pathways }\end{array}$ & $\begin{array}{c}\text { Fletcher et } \\
\text { al., } 2005\end{array}$ \\
\hline & $\begin{array}{l}\text { C57BL/6 } \\
\text { mice }\end{array}$ & $\begin{array}{l}0.01-30 \mu \mathrm{g} / \mathrm{kg} \\
\text { every } 4 \text { days } \\
\text { for } 28 \text { days }\end{array}$ & $\begin{array}{l}\downarrow \text { Cyp7a1 mRNA } \\
\text { systemically altered enterohepatic } \\
\text { circulation } \\
\uparrow \text { hepatic and serum BA pools } \\
\downarrow \text { fecal BA levels } \\
\uparrow \text { ileal transporters Asbt, Osta }\end{array}$ & $\begin{array}{l}\text { Fader et } \\
\text { al., } 2017\end{array}$ \\
\hline & Ahr-null mice & $\begin{array}{c}37 \mu \mathrm{g} / \mathrm{kg} / \\
\text { daily; } 5 \text { days }\end{array}$ & $\begin{array}{l}\downarrow \text { hepatic BA pool } \\
\leftrightarrow \text { Cyp7a1 mRNA } \\
\downarrow \text { biliary TCA, TDCA, CA and } \\
\text { DCA; hepatic T-aMCA, TUDCA }\end{array}$ & $\begin{array}{l}\text { Csanaky } \\
\text { et al., } 2018\end{array}$ \\
\hline TCDF & Ahr-null & $\begin{array}{c}24 \mu \mathrm{g} / \mathrm{kg} ; 5 \\
\text { days }\end{array}$ & $\begin{array}{l}\uparrow \text { Cyp7a1, Bacs mRNA } \\
\uparrow \text { TCDCA and TBMCA } \\
\text { shifted gut microbiota ratio of } \\
\text { Firmicutes to Bacteroidetes }\end{array}$ & $\begin{array}{l}\text { Zhang et } \\
\text { al., } 2015\end{array}$ \\
\hline
\end{tabular}




\section{Table 1}

Exposure to environmental chemicals has been demonstrated to be a significant contributor to NASH development, and the impact of the exposures and how these chemicals impact and contribute to BA homeostasis remain unclear. The recent reports on the effects and mechanisms by which environmental chemicals, including pesticides; industrial plastics; PFAS; PCBs and dioxins, alter BA homeostasis are included. 
Table 2. Environmental Chemicals Known to Modulate FXR Signaling

\begin{tabular}{|c|c|c|c|c|}
\hline Chemical & Model & Exposure & $\begin{array}{l}\text { Physiological and Molecular } \\
\text { Endpoint }\end{array}$ & Citation \\
\hline Gliquidone & \multirow{6}{*}{$\begin{array}{l}\text { U2- OS } \\
\text { cells; } \\
\text { nucleoBAS } \\
\text { FRET }\end{array}$} & \multirow[t]{6}{*}{$\begin{array}{l}10 \mu \mathrm{M} ; 30 \\
\text { mins }\end{array}$} & $\begin{array}{l}45 \% \text { FXR activation compared } \\
\text { to GW4064 }\end{array}$ & \multirow{6}{*}{$\begin{array}{c}\text { van de } \\
\text { Wiel et al., } \\
2019\end{array}$} \\
\hline Nicardipine & & & $\begin{array}{l}33 \% \text { FXR activation compared } \\
\text { to GW4064 }\end{array}$ & \\
\hline Fluticasone & & & $\begin{array}{l}60 \% \text { FXR activation compared } \\
\text { to GW4064 }\end{array}$ & \\
\hline Avermectin & & & $\begin{array}{l}\text { 84\% FXR activation compared } \\
\text { to GW4064 }\end{array}$ & \\
\hline Ivermectin & & & $\begin{array}{l}74 \% \text { FXR activation compared } \\
\text { to GW4064 }\end{array}$ & \\
\hline Triclosan & & & $\begin{array}{l}69 \% \text { FXR activation compared } \\
\text { to GW4064 }\end{array}$ & \\
\hline \multirow[t]{2}{*}{ Ivermectin } & $\begin{array}{l}\text { COS-7 } \\
\text { cells; } \\
\text { reporter } \\
\text { assay }\end{array}$ & $\begin{array}{c}0.5 \mu \mathrm{M} ; 24 \\
\mathrm{hrs}\end{array}$ & $\begin{array}{l}\text { Ivermectin activates FXR in a } \\
\text { concentration dependent } \\
\text { manner; EC50 } 200 \mathrm{nM}\end{array}$ & \multirow[t]{3}{*}{$\begin{array}{c}\text { Jin et al., } \\
2013\end{array}$} \\
\hline & $\begin{array}{l}\text { C57BL/6 } \\
\text { and } \\
\text { FXR-null } \\
\text { mice }\end{array}$ & $\begin{array}{c}1.3 \\
\mathrm{mg} / \mathrm{kg} / \mathrm{day} \\
14 \text { days }\end{array}$ & $\begin{array}{l}\text { WT-mice only: } \\
\downarrow \text { serum glucose, insulin, } \\
\text { cholesterol } \\
\uparrow \text { Hepatic Shp mRNA } \\
\downarrow \text { Cyp7a1, Cyp8b1 mRNA }\end{array}$ & \\
\hline $\begin{array}{l}\text { Ivermectin } \\
\text { GW4064 }\end{array}$ & $\begin{array}{l}\text { KK-Ay } \\
\text { mice }\end{array}$ & $\begin{array}{c}\text { Ivermectin } \\
1.3 \\
\mathrm{mg} / \mathrm{kg} / \text { day } \\
\text { GW4064 } 30 \\
\mathrm{mg} / \mathrm{kg} / \text { day; } \\
14 \text { days }\end{array}$ & $\begin{array}{l}\text { Ivermectin only: } \\
\downarrow \text { bw, serum glucose and } \\
\text { insulin } \\
\downarrow \text { Ldlr, Pepck mRNA } \\
\text { GW4064 only: } \\
\downarrow \text { Hmgcr, Sr-Bi mRNA } \\
\text { Both: } \\
\downarrow \text { serum cholesterol } \\
\downarrow \text { Cyp7a1, Cyp8b1, G6Pase } \\
\text { mRNA } \\
\uparrow \text { Bsep mRNA }\end{array}$ & \\
\hline $\begin{array}{l}\text { Ivermectin } \\
\text { Doramectin } \\
\text { Abamectin } \\
\text { GW4064 }\end{array}$ & $\begin{array}{l}\text { KK-Ay } \\
\text { mice }\end{array}$ & $\begin{array}{l}\text { Avermectin } \\
\text { analogues } \\
1.3 \\
\text { mg/kg/day }\end{array}$ & $\begin{array}{l}\text { Avermectin analogues only: } \\
\downarrow \text { LW:BW, serum triglycerides, } \\
\text { cholesterol }\end{array}$ & $\begin{array}{l}\text { Jin et al. } \\
2015\end{array}$ \\
\hline
\end{tabular}




\begin{tabular}{|c|c|c|c|c|}
\hline & & $\begin{array}{c}\text { GW4064 } 30 \\
\mathrm{mg} / \mathrm{kg} / \text { day; } \\
14 \text { days }\end{array}$ & $\begin{array}{l}\downarrow \text { Cyp8b1, Srebp-1c, Scd-1 } \\
\text { mRNA } \\
\uparrow \text { Shp, Bsep, Akr1b7 mRNA }\end{array}$ & \\
\hline $\begin{array}{c}\text { Triclosan } \\
\text { CDCA }\end{array}$ & Huh7 cells & $\begin{array}{c}\text { Triclosan } 10 \\
\mu \mathrm{M} \\
\text { CDCA } 50 \\
\mu \mathrm{M} ; \\
24 \mathrm{hrs}\end{array}$ & $\begin{array}{l}\text { Triclosan either very weak } \\
\text { agonist or partial antagonist } \\
\text { competing with CDCA for } \\
\text { binding of FXR }\end{array}$ & $\begin{array}{c}\text { van de } \\
\text { Wiel et al., } \\
2019\end{array}$ \\
\hline \multirow[t]{2}{*}{$\begin{array}{l}\text { Gentamycin } \\
\text { Vancomycin }\end{array}$} & $\begin{array}{c}\text { Human } \\
\text { Intestinal } \\
\text { Failure } \\
\text { Patients } \\
\text { with } \\
\text { cholestasis }\end{array}$ & - & $\begin{array}{l}\text { Disrupted FXR signaling } \\
\downarrow \text { ASBT, OSTa/B mRNA } \\
\downarrow \text { serum FGF19 } \\
\uparrow \text { CYP7A1, CYP8B1, } \\
\text { CYP27A1 mRNA }\end{array}$ & \multirow[t]{2}{*}{$\begin{array}{c}\text { Xiao et al. } \\
2018\end{array}$} \\
\hline & $\begin{array}{l}\text { C57BL/6 } \\
\text { mice }\end{array}$ & $\begin{array}{l}\text { Gentamycin } \\
2 \mathrm{~g} / \mathrm{L} \\
\text { Vancomycin } \\
500 \mathrm{mg} / \mathrm{L}\end{array}$ & $\begin{array}{l}\text { Antibiotic treatment altered BA } \\
\text { transport in liver and ileum } \\
\uparrow \text { T } \beta \text { MCA }=\downarrow \text { Fgf15 mRNA } \\
\uparrow \text { Cyp7a1, Cyp27a1, Mrp3, } \\
\text { Mrp4, Mdr3 mRNA }\end{array}$ & \\
\hline
\end{tabular}

Table 2

Very few environmental chemicals are known to modulate FXR signaling, however the majority of them are FDA approved therapeutics. 
Human Bile Acid Synthesis Liver BA transporters
Intestinal BA transporters
Human BA synthesis genes
Mouse BA synthesis genes

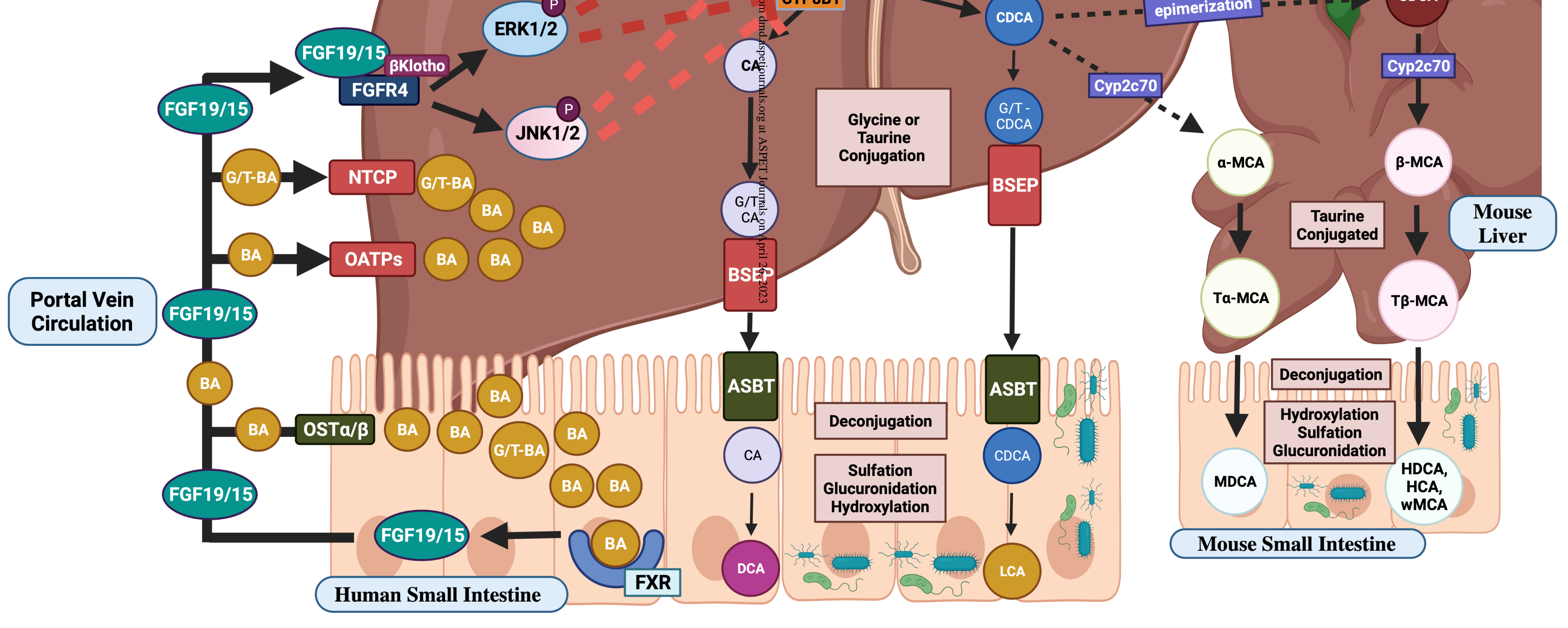

